„Bohemistyka” 2021, nr 4, ISSN 1642-9893

Joanna DERDOWSKA

DOI: $10.14746 /$ bo.2021.4.2

Uniwersytet Śląski w Katowicach

\title{
Wolności literatury? \\ Wartościowanie wolności w debacie o literaturze zaangażowanej w Czechach na początku drugiej dekady XX w.
}

Keywords: Czech literature, engaged literature, freedom, literary critics, anticommunism

Słowa kluczowe: literatura czeska, literatura zaangażowana, wolność, krytyka literacka, antykomunizm

\section{Abstract}

Participants of a debate concerning engagement in literature (particularly in poetry) that went though in some Czech cultural and literary magazines in 2012-2013 often used the category of freedom. Using this debate as an example this article follows a pattern in a public, also intellectual, discourse, in which the notion of freedom serves for defense of individualistic positions against a supposed peril of community values perceived as subjugation of an author as an individual artist. In the search of a potential remedy for the polarization of notions the article shifts towards the role of a recipient in the process of reading.

W debacie, która przebiegła w czeskich czasopismach literackich w latach 2012 -2013 na temat znaczenia zaangażowania w literaturze (szczególnie poezji) jej uczestnicy wielokrotnie posługiwali się kategorią wolności. Na przykładzie tej debaty artykuł pokazuje, jak w dyskursie publicznym, także intelektualnym, pojęcie wolności służy obronie pozycji indywidualistycznych przeciw domniemanemu zagrożeniu wspólnotowością rozumianą jako forma zniewolenia twórcy jako jednostki. W poszukiwaniu potencjalnego remedium na spolaryzowanie pojęć zwraca się ku roli odbiorcy w procesie lektury.

W historii literatur narodowych z różną regularnością i różną częstotliwościa obserwować można fale uwalniania literatury (i szerzej pojętej sztuki) z okowów życia społecznego, w odpowiedzi na które 
nadchodzi często nurt przeciwny, starający się osadzić twórczość literacką w kontekście społecznym, a często nadać jej w nim ponadto pewne znaczenie sprawcze. W binarnym skrócie konflikt ten opisać można jako zygzak pomiędzy estetyzmem a ideologicznością, między indywidualizm a kolektywizmem. Proces historycznoliteracki nie przebiega rzecz jasna po gładkiej trajektorii sinusoidy Krzyżanowskiego, którą niekiedy kreśli się na szkolnych tablicach na potrzeby dydaktyczne. W uproszczeniu można jednak śmiało przyjąć, że reakcją na parnasizm zwykle bywa jakieś burzycielstwo, a ucieczką od socrealizmu - jakaś poezja dnia powszedniego. Napięcie między tymi wartościami chciałabym zaprezentować na tle debaty dotyczącej tzw. literatury zaangażowanej, która kilka lat temu przebiegła na łamach kilku czeskich czasopism literackich i kulturalnych, przede wszystkim: „Host”, „A2”, „Tvar” i „Psí víno”. Jej uczestnicy wielokrotnie posługiwali się kategorią wolności. Interesujący okazał się w nich zwłaszcza sposób i konteksty określania jako „wolnej” tej literatury, która znajduje się na biegunie opiewającym indywidualizm i odżegnującym się od sfery politycznej.

Jaki przebieg miała owa debata o zaangażowanie? Na początek należy zaznaczyć, że była ona na bieżąco obserwowana i komentowana przez czeskich krytyków literatury i literaturoznawców, i doczekała się kilku artykułów syntetycznych, do których pozwalam sobie odesłać czytelnika ${ }^{1}$, a przebieg samej debaty nakreślę tu skrótowo. Jeszcze w latach dziewięćdziesiątych, podobnie zresztą jak i w Polsce, wyraźną tendencją światopoglądową w Czechosłowacji, a następnie w Czechach było przeświadczenie, że literatura wraz z przełomem ustrojowym uwolniła się (zwróćmy od razu uwagę na zastosowanie tu słowa wolność) od polityki i jej wpływu (czyli ograniczeń), oraz przekonanie, że powinna ona od tego momentu pozostać raz na zawsze oddzielona od polityki. Dla ilustracji przywołuję tu za Karlem Pioreckim słowa Jiřego Kratochvila z roku 1993:

\footnotetext{
${ }^{1}$ Najbardziej uporządkowanego przeglądu jej rozwoju oraz konceptualizacji sa-
} mego pojęcia zaangażowania w poezji, także w kontekście historycznym, dokonał Karel Piorecký w artykułach: Piorecký 2012 i 2013.
[...] není nic navzájem si vzdálenějšího než politika a literatura, a tyto dva prostory se dotýkají jen proto, aby literatura byla snad obranou individuální svobody před jakoukoliv politickou manipulací a snad obranou duše před jakýmkoliv inovativním kolektivním duchem (Kratochvil 1993, za: Piorecký 2013, s. 14).

W swym artykule Kratochvil nie odżegnuje się od tematyki politycznej jako od tematu literackiego, dopuszcza ją jako jeden z elementów świata przedstawionego, zastosowany dla ukazania egzystencjalnej walki człowieka $\mathrm{z}$ władzą. $\mathrm{W}$ tym samym tekście pisze także:

Vynořuje se tu svět, který je vědomým protipólem každé kolektivní utopie, svět individuálních mytologií a autistických mystérií, svět obrácený $\mathrm{k}$ jedinci, a ne už ke společnosti, národu (Kratochvil 1993, s. 1).

Nie minęło jednak parę lat, a kontakt literatury i polityki powrócił na łamy czasopism i zaplecza ich redakcji z nową falą zainteresowania. Upolitycznieniu, a nawet upartyjnieniu, uległa choćby orientacja prowadzonych przez Jakuba Patočkę „Literarnich novin”. W związku z tym w 2005 nastapił rozpad zespołu redakcyjnego, z którego znaczna część redaktorów odeszła, by założyć nowe pismo literacko-kulturalne „A2”. Libuše Běluňková, redaktorka naczelna nowego tygodnika nie zamierzała jednak ograniczać spektrum zainteresowań redaktorów i autorów do samej literatury, przeciwnie, w artykule wstępnym do numeru zerowego pisała wówczas:

Kulturu hledáme a zkoumáme u všech veřejně činných osob či skupin, včetně politiků. Myslíme si, že nahlížet společenské a politické dění prizmatem kultury může být nejen užitečné, ale i zábavné. [...] [Kultura] není bezzubá (Běluňková 2005, s. 2).

W podobnym czasie wyrażana zaczęła być także publicznie refleksja nad kryzysem literatury, przede wszystkim poezji, jej poszukiwaniami i nowym, swatanym randez-vous z zaangażowaniem. Najwięcej na ten temat dowiadujemy się z miesięcznika „Host”, zwłaszcza z numerów z lat 2003 i 2008. W tym ostatnim, przy okazji rocznic lat „ósemkowych”, którymi z upodobaniem ramuje się tradycyjnie czeską i słowacka historię dwudziestego wieku, zaangażowaniu poezji poświęcony został cały numer czasopisma, zawierający ankiety 
wśród twórców i krytyków, z których większość o możliwości skoligacenia polityki i literatury wyrażała się jednak sceptycznie (por. Urban 2008). Debata między poetami młodszego pokolenia przesunęła się następnie na łamy dwutygodnika „Tvar”, ale prawdziwa jej eskalacja nastąpiła dopiero w roku 2013, kiedy to w pozornie marginalnej glosie pt. Krize lyrického věku Eva Klíčová zarzuciła redaktorom czasopism „Tvar” i „A2" lewicowy profil, porównując ich praktyki redaktorskie do tych z lat pięćdziesiątych (Klíčová 2013). Ten króciutki tekst stał się pretekstem do serii reakcji, które jesienią 2013 przetoczyły się przez takie media jak „Britské listy”, „Deník referendum” oraz naturalnie przez zaatakowane pisma „Tvar” i „A2”.

Debata dotyczyła takich problemów jak dopuszczalność koncepcji rozwoju (a więc i regresu) w kulturze, ideologia, dyskurs lewicy, zaangażowana recepcja, a także wolność twórcza i autonomia autora. Ferment, który wniosła, był jednak raczej hermetyczny i środowiskowy. Historyk i teoretyk literatury Petr A. Bílek przypuszcza, że „s odstupem dalších desetiletí se budoucím literárním historikům budou dobové diskuse o angažovanosti jevit stejně bizarně jako »diskuse« o pravosti RKZ ve dvacátých letech 20. století či o socialistickém realismu v letech osmdesátých" (Bílek 2015). W tym artykule powracam do nich, by pomówić o sposobach operowania w nich koncepcją wolności.

Podczas ich lektury w pamięci czytelnika rezonować może artykuł, który w roku 1968 opublikował w „Literárních listach” Jindřich Chalupecký, a który nosił nie inny i nie mniej znaczący tytuł jak Literatura a svoboda (2003). Artykuł Chalupeckiego, poruszający problematykę przenikania się świata literatury i polityki, otworzyła wówczas seria cytatów ze współczesnych mu autorów opiewających stalinowskie morderstwa sądowe lat pięćdziesiątych, na podstawie których Chalupecký wysnuł krytykę usługowej roli twórczości literackiej wobec panującej ideologii. W swej krytyce nie pominą jednocześnie ulegania poezji tendencjom nacjonalistycznym, którą określił jako „tak samo głupią jak późniejsza poezja epoki stalinowskiej” (Chalupecký 2003, s. 452). Wszelkie fascynacje literatury ideologią, czy to prawicową czy marksistowską, oraz traktowanie literatury jako narzędzia, Chalupecký uznał za niebezpieczne dla zachowania niezależności i integralności twórczej osoby pisarza.

I tak też właśnie, jako zniewolenie, cenzura i ograniczenie postrzegane są wciąż często również przez dzisiejszych krytyków i intelektualistów postulaty włączenia literatury (poezji) i krytyki literackiej w życie społeczne. Co znamienne dla współczesności, czasów realizmu kapitalistycznego, w tekstach analizowanej debaty słowo wolność nie pojawia się zwykle w głosach postulujących zaangażowanie, lecz w reakcjach na nie. Wolnością określa się w nich wartość, która ma być zagrożona. Związany z grupą surrealistyczną Bruno Solař́ik pisze na przykład:

Kdo to všechno inicioval - tu snahu vymýtit, odmítat, potírat, netrpět faktickou svobodu tvorby ve jménu údajné svobody lidu? (Solařík 2013).

aby następnie zacytować (wersalikami) André Bretona:

Nikdy žádné př́kazy v umění, at’ se stane cokoli! (Solařík 2013).

Zatrzymajmy się jeszcze na chwilę przy samym określeniu ,zaangażowanie". Dla wielu intelektualistów z pokolenia, dla którego transformacja ustrojowa w roku 1989 była wydarzeniem formatywnym i jednym z największych sukcesów ich współczesnych, już samo to słowo bowiem zostało definitywnie zdewaluowane $\mathrm{i}$ brzmi podobnie niepokojąco, jak tak śmiałe określenia jak ,klasa społeczna” czy „związki zawodowe”. Uznawany teoretyk literatury Pavel Janoušek o określeniu „,zaangażowanie” pisze, że „śmierdzi bolszewizmem”, a w artykule poświęconym przebiegowi debaty dodaje wprost:

Když se v českých literárních časopisech začalo objevovat slovo angažovanost, a to již nikoli ve spojení s normalizačním pochlebováním komunistickému režimu, ale jako pozitivní úkol pro nově vznikající poezii, připadalo mi to podivné a bláznivé" (Janoušek 2012).

Nasuwa się pytanie o źródło takiej właśnie dystrybucji określeń wartościujących i pomijanie w tym dyskursie okoliczności, że literaturą zaangażowaną można określić nie tylko oficjalną literaturę cza- 
sów stalinowskich, ale równie dobrze czechosłowacki samizdat czy polski drugi obieg, których produkcja i konsumpcja jednoznacznie opisywane są w kategoriach paradygmatu wolności ${ }^{2}$.

Wróćmy jednak do kategorii wolności, która w tym sporze ma być rzekomo zagrożona ze strony postulatów zaangażowania. Janoušek, chcąc zdeprecjonować ich znaczenie, podkreśla, że społeczność, której całe zamieszanie dotyczy, jest bardzo wąska. Ilość uczestników życia literackiego, to jest czytelników i użytkowników czasopism literackich jest, jak podkreśla, znikoma i ma tendencję spadkową. Janoušek prowokuje środowisko, pisząc, że czasopism krytyczno-literackich nie czytają nawet ci, którzy powinni być zainteresowani ich lekturą ze względów zawodowych: studenci, nauczyciele akademiccy, autorzy. Stąd według niego wynika frustracja i potrzeba zwrócenia uwagi na krytykę. Janoušek diagnozuje trzy potencjalne drogi przywrócenia doniosłości literaturze i krytyce literackiej: jedną z nich ironicznie nazywa królewska, czyli prowadzaca przez wyniosły parnasizm, drugą - „trávníčkowską”, od nazwiska Jiřego Trávníčka, literaturoznawcy zajmującego się socjologią literatury i badaniem czytelnictwem, która to droga prowadzić by miała przez podbijanie statystyk czytelnictwa przez literaturę łatwą i przystępną; oraz drogę trzecią, szukającą dostrzegalności właśnie poprzez poezję zaangażowaną. Według Janouška ta ostatnia droga prowadzić chce do ocenzurowania literatury tak, ,aby v ní zůstali jen básníci ideově správní, tj. levicoví kolektivisti, kteří se bezúčelně nepatlají v nitrech" (Janoušek 2013, s. 12). Krytykowane przez Janouška zaangażowanie, które utożsamia on $\mathrm{z}$ cenzurą i zniewoleniem, jest więc według niego reakcją na frustrację, próbą wyjścia literatury i krytyki literackiej ze społecznego niebytu.

${ }^{2}$ Głosy z drugiej strony debaty podkreślały raczej fakt, że literatura jest z gruntu polityczna w samej swej esencji, jak czynią to choćby w swoistym manifeście Jan Bělíček i Marta Martinová (wówczas podpisująca się jako, nomen omen, Svobodová, por. Bělícek a Martinová 2013). W sobie własnej frazie rozwija i problematyzuje to przekonanie także surrealista Frantisek Dryje (2013).
Tu znów z pomocą przyjść może Chalupecký. Pisząc swój artykuł pod koniec lat sześćdziesiątych, wprowadził on do niego również orzeźwiającą perspektywę krytycznego spojrzenia także na świat zachodni, który autor postrzegał wprawdzie jako świat dobrobytu, lecz nie brakło mu głębokiego sceptycyzmu co do położenia twórcy w realiach hipertrofii wolności indywidualnych. Chalupecký podkreślał, że w przeciwieństwie do systemów totalitarnych, w których twórca jest zniewolony przez naciski polityczne i, chcąc utrzymać postawę etyczną, musi rezygnować z własnego statusu społecznego i uciekać się do emigracji wewnętrznej, w liberalizmie pisarz posiada prawo do wolności, lecz prawo to implikuje, że twórca staje się niezauważalny, odsunięty na margines, po prostu nieważny. Chalupecký pisze:

Spor mezi apolitičností a političností literatury se tedy zdá bezvýchodný. Političnost ji vede do zneužití, ale apolitičnost ji odsuzuje k neúčinnosti (Chalupecký 2003, s. 455).

Czy to nie właśnie świadomość marginalizacji, powstałej na skutek wszechobecnej wolności rodzi między innymi w krytykach literatury potrzebę zaangażowania przedmiotu swojej pracy i siebie samych? Wyjścia poza opustoszałe getto nieistotności i obojętności, i sprawienia, że literatura i życie będą posiadały znów jakąś wagę? Chalupecký w swoim sceptycyzmie posuwa się jeszcze dalej, kwestionując nawet możliwość wolności w społeczeństwie konsumpcyjnym:

Člověk, má-li zůstat člověkem, nemůže přijmout svůj svět jako něco hotového. Musí se na světě účastnit vlastním tvořením: svět, který má, musí být z jeho svobody. Tíseň, kterou zakouší ve světě konzumní společnosti, je tíseň cizoty; není tu místa pro jeho svobodu (Chalupecký 2003, s. 457).

Jeśli silne i kasandryczne słowa wypowiedziane z głębin socjalistycznej republiki były słuszne, to niechybnie odnajduja zastosowanie współcześnie. Totalna wolność słowa według Chalupeckiego nie tylko powoduje, że nikt wolnego mówcy już nie słucha i nie słyszy, lecz także sama wolność w tym systemie może zostać poddana w wąt- 
pliwość przez alienację. Odbijając się od tego najniższego punktu, od skostnienia w wolności, Chalupecký wyjaśnia dalej:

Je vůbec něco zastaralého na pojmu literatura. Říkává se, že literatura má být svědomím ostatních, vést je, hlásat pro ně svobodu. Ale ani spisovatel nemůže pro nikoho vymyslet život. Může jen problematizovat, co se ostatním zdá jisté, znepokojovat jejich vědomí, způsobovat, že se budou muset sami o sobě rozhodovat, že se v nich samých začne jejich život měnit (Chalupecký 2003, s. 459).

Nie powinno więc zapewne dziwić, że podobny zwrot koncepcyjny pojawił się także w omawianej czeskiej debacie sprzed kilku lat. Był to mianowicie zwrot ku czytelnikowi zaangażowanemu. $\mathrm{W}$ intencji rozbicia opozycyjnego i konfliktowego postrzegania debaty ${ }^{3}$ Roman Kanda (2013) odwrócił perspektywę i skierował uwagę na aktywne zaangażowanie czytelnika w lekturę, dzięki któremu absolutna opozycja między autonomią i zaangażowaniem autora czy tekstu traci na znaczeniu. Co ciekawe, także w Polsce, podczas jednej z debat na temat literatury zaangażowanej, które swoją drogą przebiegały w podobnym czasie, co w Czechach, Przemysław Czapliński proponował, by zamiast o literaturze zaangażowanej mówić raczej o literaturze angażującej, czyli takiej, która aktywuje czytelnika do krytycznego myślenia, takiej, która ma bezpośredni związek z życiem. Pomimo że uwaga Kandy w ramach omawianej debaty nie została już później rozwinięta, wydaje się, że to właśnie dzięki takiej perspektywie mogłoby dojść do przełamania zautomatyzowanego łączenia koncepcji zaangażowania ze zniewoleniem i do odwrócenia wartościowania poprzez zastosowanie kryterium, czy może nawet postulatu - wolności poprzez zaangażowanie.

\section{Literatura}

B ě lí č e k Jan, M a r t i n o vá Marta, 2013, Ideologie a literatura. Co se skrývá pod nálepkou levicového literárního časopisu? „A2”, $\mathrm{nr} 17$. Online: https://www. advojka.cz/archiv/2013/17/ideologie-a-literatura [dostęp 4.01.2021]

B ěl u ň k ová Libuše, 2005, Editorial, „A2”, č. 0, s. 2.

${ }^{3}$ Rozbić polaryzację debaty próbował także Adam Boržič (2013).
B íl e k Petr A., 2015, Pokus o dějiny nové literatury. Od volnosti k mnohosti, ale pořád v souřadnicich. „A2”, nr 04. Online: https://www.advojka.cz/archiv/ 2015/4/pokus-o-dejiny-nove-literatury [dostęp 4.01.2021].

B o r ž i č Adam, 2013, Slovo a svět: Ke sporu o literaturu a ideologii, „Britské listy”, 25.09. Online: https://blisty.cz/art/70250-slovo-a-svet-ke-sporu-o-literaturua-ideologii.html [dostęp 4.01.2021].

Dryje František, 2013, Čtyři způsoby, jak nerozuměti literatuře. Online: http://www.itvar.cz/cz/2013/2013-dryje-705.html [dostęp 4.01.2021].

Ch a l u p e cký Jindřich, 2003, Literatura a svoboda, [w:] Přibáň, Michal (ed.), $Z$ dějin českého myšlení o literatuře 3 (1958-1969), Praha, s. 448-460.

J a n o u š e k Pavel, 2012, Poslední tah králem. Ještě k té angažovanosti, „Tvar”. Online: http://old.itvar.cz/cz/2012/06-2012-janousek-220.html [dostęp 4.01.2021].

J a n o u š e k Pavel, 2013, Spát a revoluce, aneb tři zdroje a tři součásti české angažované teorpoezie neboli co dělat? „Tvar” č. 18, s. 12-13.

K a n d a Roman, 2013, Spory o hledisko aneb diskuse, která stojí na hlavě „Deník Referendum" 2.10. Online: http://denikreferendum.cz/clanek/16518-spory-o -hledisko-aneb-diskuse-ktera-stoji-na-hlave [dostep 4.01.2021].

K lí č o vá Eva, 2013, Kritéria lyrického věku, „Host”, č. 6, s. 27.

K r a t o c h v i 1 Jiří, 1993, Česká literatura a politika. „Tvar”, nr 27-28, s. 1.

P i o r e c k ý Karel, 2012, Angažovaná poezie: souřadnice pojmu, „Psí víno”, č. 59/60, s. $23-29$.

P i o r e c k ý Karel, 2013, O diskusi, které se nechce spát, „Tvar”, č. 24 (17), s. 14-15.

Solařík Bruno, 2013, K hledisku v umění, „Britské listy”, 20.09. Online: http://www.blisty.cz/art/70181.html [dostęp 4.01.2021].

U r b a n Miloš, 2008, Jak jsem dal spálil parlament. „Host”, č. 7, s. 2. 